\title{
From Multiversity to Postmodern University
}

\author{
Claire Donovan
}

\section{Introduction}

This chapter outlines the idea of the multiversity and of the postmodern university, and describes their defining features. The chapter then further explores these concepts using three examples: the university community, university governance, and the role of the university within wider soci-ety. The chapter concludes with a discussion of the strengths and weaknesses of the multiversity and postmodern university, what they do and do not share in common, and what questions these competing (yet often very similar) visions of the university raise for our understanding of higher education institutions (HEIs) today.

There are several ideas about the function or mission of the university, which have evolved and transmuted over time (Scott, 2006: 3; Donovan, 2013: 27-31), and these provide important context for understanding the idea of the multiversity and the postmodern university. For example, the pre-modern university (sixteenth to nineteenth century) is characterised as a cloistered monastic community that taught the Scholastic method where human reason was subordinate to doctrinal (or biblical) truth, and this training was required for those within administrative and professional elites. The modern university (nineteenth century) was grounded on the notion of fallible truth, where doctrinal truth could be contested, and this education based on personal enlightenment and preparation for leadership was required for aristocratic elites and expanding professional and administrative classes. It was also where 'high culture' was preserved in the face of modernisation and industrialisation. The late-modern university (late nineteenth century onwards) was based on objective, scientific truth, taught to expanding numbers of (social) scientific and administrative classes who were selected on the basis of merit. In addition to teaching, it had a research function where subject specialisation underpinned national economic competitiveness. It was also where the 'two cultures' of the humanities and the sciences became polarised (Snow, 1959; Leavis and Yudkin, 1962). The multiversity and the postmodern university are located within late modernity, and both view universities as complex and inconsistent institutions, although the vision of the multiversity is optimistic while that of the postmodern university remains largely pessimistic.

In 1963, Clark Kerr presented the idea of the multiversity in his book The Uses of the University. The term 'multiversity' denotes a group of elite research universities in the United States, which 
he viewed as located at the heart of national and international economic growth and social, political and cultural development, and whose characteristics set them apart from the traditional late-modern idea of the university. He defined the key features of the multiversity as plurality in terms of having multiple purposes, centres of power and clienteles; and inconsistency through embracing many truths, being comprised of several different communities, and serving conflicting interests both internally and externally (1995: xiv, 103). For Kerr, earlier visions of the university are 'ideal types' while the multiversity is grounded in reality.

The idea of the postmodern university gained traction in the 1990s, most notably in Anthony Smith and Frank Webster's 1997 edited book The Postmodern University? The concept was applied to the whole university sector (i.e. teaching and research across all HEIs) originally in the United Kingdom, although later extended to universities in late-modern neoliberal societies (Krücken et al., 2007: 8). The postmodern university is characterised by 'massification' or a large increase in student numbers, and students becoming consumers of a non-elite education with an increasing vocational focus. It is also marked by a culture of managerialism, with academic staff subjected to audit of teaching outcomes and research productivity. Traditional ideas of the university are subverted by difference and uncertainty: there is no longer any central unifying principle to collectively hold HEIs together; the notion of an academic community has broken down; and authoritative knowledge claims or universal truths no longer exist.

\section{The multiversity}

The concept of the multiversity was presented by Clark Kerr in his 1963 book The Uses of the University. Kerr was a professor of economics and industrial relations who in 1952 was appointed the first Chancellor of Berkeley, and in 1958 went on to become the 12th President of the University of California. The Uses of the University was based on a three-part series of Gulkin Lectures presented by Kerr during April 1963 at Harvard University's John F. Kennedy School of Government. The multiversity concept focused on a select group of around 20 elite American research universities, with Berkeley and Harvard at its pinnacle. It also denoted a university located on a single campus and not, as is sometimes thought, a university spread across multiple campuses (i.e. a multi-university).

The American educator and reformer Abraham Flexner had likened the university to an organism, all of its parts bound to each other and working in harmony to constitute the whole. For Kerr, this was not the case with the multiversity where 'many parts can be added and subtracted with little effect on the whole or even little notice taken or any blood spilled. It is more a mechanism - a series of processes producing a series of results - a mechanism held together by administrative rules and powered by money' (1995: 15). This analogy paints a picture of the multiversity as a machine that can be constantly recalibrated and which operates like a business concern, its main product being new knowledge. Given Kerr's academic specialisms, it is unsurprising that he understood the multiversity first and foremost in the context of its broader social and economic situation. He believed that the new knowledge produced by the multiversity was an 'invisible product' that was the 'most important factor in economic and social growth' and possibly 'the most powerful single element in our culture, affecting the rise and fall of professions and even of social classes, of regions and even of nations' (1995: xiv). The multiversity therefore occupied a pivotal role in economic growth, international competition, and political, social and cultural development; and the knowledge it produced was actively being sought by wider society and by government agencies and commerce in particular (1995: xv, viv).

As has already been noted, the key features of the multiversity are its plurality and its inconsistency. Plurality is evident in the multiversity having multiple purposes and serving many 
clienteles: producing new knowledge, educating its students, attracting research funding, communicating research findings to various publics, serving society, being critical of society, and responding to the needs of policymakers, commerce and agriculture. It also has multiple centres of power, leading to the need for university governance rather than government, an idea later elaborated on in this chapter. Inconsistency is found in the multiversity having a range of conflicting relationships internally and externally. Internally, the multiversity is comprised of varied communities with competing interests: for example, academics, undergraduate students, graduate students, administrators, managers, humanists, social scientists, scientists, and professional schools (1995: 14-15). As Kerr puts it, 'a community should have a soul, a single animating principle; the multiversity has several - some of them quite good, although there is much debate on which souls really deserve salvation' (1995: 15). In its external relationships, Kerr describes the multiversity as having fuzzy edges, in that it seeks to connect with alumni, legislators, agriculture and commerce, which have pre-existing relationships with one or more of the university's internal communities. The multiversity is also inconsistent in that it embraces many truths, with its variety of scholarly communities being 'marked by many visions of the Good, the True, and the Beautiful, and by many roads to achieve these visions' (1995: 103).

The multiversity is therefore constantly changing its shape, showing 'how adaptive it can be to new opportunities for creativity; how responsive to money; how eagerly it can play a new and useful role ... how fast it can neglect some of its ancient virtues' (1995: 34). Yet within this amorphous nature, it remains above all an elite institution, and ' $[p]$ rotection and enhancement of the prestige of the name [of an institution] are central to the multiversity'. A university's name or brand 'stands for a certain standard of performance, a certain degree of respect, a certain historical legacy, a characteristic quality of spirit' that is vital for its internal communities and for its external standing with government, commerce, and the public at large (1995: 15).

As we see in this chapter's conclusion, the multiversity concept courted controversy. In typically robust fashion, Kerr stated in his 1963 preface that, 'Instead of platitudes and nostalgic glances backward to what it once was, the university needs a rigorous look at the reality of the world it occupies today' (1995: xiii). Three decades later, in a preface to a new edition of The Uses of the University, Kerr reflected that what might today seem be commonplace descriptions were regarded by many at the time as 'blasphemy' (1995: vii-viii).

\section{The postmodern university}

The idea of the postmodern university emerged during the 1990s, originally with a UK focus. The most influential text was The Postmodern University? Contested Visions of Higher Education in Society, a book edited by Anthony Smith and Mark Webster (1997a), and contributors to this volume were largely sociologists and higher education scholars based at UK universities. While the multiversity was concerned with a relatively small number of elite research universities, the postmodern university concept was applied to all types of HEI, covering a diverse range of institutions and array of institutional missions. Just as the term 'postmodern' resists classification (Griffin, 1997: 6), the idea of the 'postmodern university' similarly attracted varied and competing definitions to the extent that many felt that there was no unifying concept of the university and we should 'cease our search for an underpinning rationale' (Smith and Webster, 1997b: 9). A collective narrative, however, emerged that presented the postmodern university as 'completely fractured from what went before, where university functions are contrarily regarded as dysfunction, and where different rules (or indeed no rules at all) apply' (Donovan, 2013: 31). If anything, the postmodern university was characterised by 'heterogeneity and the lack of any 
central organizing principle' (Donovan, 2013: 28) which acted to 'subvert many of the tradi-

tional justifications of the university' (Smith and Webster, 1997b: 5).

Although there was no fixed definition of the postmodern university, competing pictures held in common some unifying features (or family resemblances) such as 'a shared concern with difference, diversity, and fragmentation' (Donovan, 2013: 25). We also find recurring 'gothic' themes such as the detrimental effects of 'massification' or a large increase in student numbers on the educational experience, the replacement of collegial forms of university governance with a culture of managerialism, a state-imposed requirement for research to meet instrumental economic or societal needs, the break-up of the academic community, and the end of authoritative knowledge claims or universal truths.

Donovan (2013: 28-31) analysed the idea of the postmodern university by examining the literature on its teaching and research functions and its cultural impact. Rapid expansion in undergraduate numbers, and the advent of student loans to pay for this education, is viewed to have had negative consequences. First, the relationship between faculty and students is held to have fundamentally shifted. Students have become consumers purchasing training or 'entitlement' for the employment market. As 'customers' the balance of power between faculty and students has shifted in students' favour. Second, this entails that students are purchasing a non-elite education with an increasingly vocational emphasis. As Peter Scott puts it, 'Through their redesignation as customers, students are both empowered, because their immediate demands are more likely to be satisfied, and diminished, because their longer-term needs may be ignored and their participation as a symbolic, transcendental, even magical, experience will be denied' (1997: 48).

Economic instrumentalism is felt to be reshaping the research function of the postmodern university. This is encountered in the form of pressure for academics to meet targets for obtaining research funding, the audit of the quality of their research 'outputs' or publications, and the increasing requirement for research to meet economic or societal needs. These targets are policed by university managers, whose power has replaced collegial forms of decision-making. Research in the postmodern university is also held to be marked by individual hyper-specialisation to the extent that the idea of academic disciplines is now 'symbolic' and the academic community 'is a kind of fiction' (Smith and Webster, 1997b: 3, 5). This hyper-specialisation, combined with loss of faith in the Enlightenment project and a rejection of 'grand narratives' or authoritative knowledge, entails that 'knowledge as we have known it in the academy, is coming to an end' (Griffin, 1997: 3).

The university's function of preserving and transmitting 'high culture' is perceived to have disappeared. For example, an effect of 'massification' is that university education is no longer the domain of a small cultural and political elite, so students instead 'receive a purely instrumental education' (Kumar, 1997: 30). Another argument is that if we have reached the 'end of meaning' (Donovan, 2013: 31) then either there can be no 'consensus on what constitutes high culture' (Kumar, 1997: 30) or the university must preserve and transmit many cultures, and not just one (Bauman, 1997). Kumar believes that the postmodern university has lost its critical cultural role. He maintains that 'the function of universities is not to swim with the tide but to go against it' and while 'many accounts of the university ... stress its maintenance and enrichment of a certain high culture against the encroachments of business, politics, and everyday life', that is no longer the reality (1997: 30).

In many respects, the idea of the postmodern university echoes key features of Kerr's multiversity introduced three decades earlier, particularly in their shared focus on inconsistency and plurality. For example, the following quote could be taken from either: 'There is a multiplicity of differences: different academics pursuing different knowledges, different teams of researchers combining and recombining to investigate shifting topics, different sorts of students following 
different courses, with different models of study and different concerns among themselves, different employment arrangements for different types of staff' (Smith and Webster, 1997c: 104). We also find shared concerns with particular issues such as greater links between universities and national social and economic interests, the seemingly contingent status of truth or knowledge, and the role of the university in critiquing wider society. Yet, rather remarkably, The Postmodern University? only refers once to the multiversity concept. While the multiversity is forwardlooking and seeks to engage positively with the changing nature of the university and society, theorists of the postmodern university tend to look backwards nostalgically to more traditional models of the university and mourn their loss.

In order to understand the idea of the multiversity and postmodern university more deeply, this chapter now explores three examples: the university community, university governance, and the role of the university within wider society.

\section{Example 1: The university community}

Kerr likened the community of the pre-modern university to 'a village with its priests', and described the modern university as a 'one-industry town - with its intellectual oligarchy'. In comparison, the multiversity is 'a city of infinite variety' (1995: 31). Kerr believed that the multiversity was comprised not of one community but of several communities of different types of students, academics, professional, administrative and managerial staff, all with different and competing interests. While there was less sense of community than within the pre-modern university, and less sense of purpose than the modern university, the multiversity offered greater and more varied opportunities: 'Some get lost in the city; some rise to the top within it; most fashion their lives within one of its many subcultures .... There are also more refuges for anonymity - both for the creative person and the drifter.' The multiversity was therefore comprised of a series of communities in constant flux, and had no fixed shape. It is held together 'by a common name, a common governing board, and related purposes' (1995: 1).

Students were likely to be 'older ... more vocationally oriented, more drawn from all classes and races' and highly competitive with each other (1995: 31). Kerr believed they related less to a student community but more to its various subgroups. He draws on the work of Burton Clark and Martin Trow (1960) to identify various student tribes: collegiate ('fraternities and sororities and the athletes and activities majors'), academic ('the serious students'), vocational ('seeking training for specific jobs') and non-conformist ('political activists, the aggressive intellectuals, and the bohemians'). However, while the multiversity offers a variety of opportunities, this can be problematic as students struggle to find identity and security, and so ' $[\mathrm{t}]$ he casualty rate is high' (1995: 31-2).

Faculty members would have experienced a great deal of change during their careers. In addition to traditional lecturing and research posts, consultant and administrator roles were created to manage both the external demand for research and navigate more complex form of internal organisation. Several faculty members responsible for managing research and teaching assistants, and departments or institutes, had become administrators. Kerr cites Merle Tuve (1959) when describing the life of a new phenomenon, the 'affluent professor': 'a rat race of business and activity, managing contracts and projects, guiding teams and assistants ... making numerous trips, sitting on committees for government agencies, and engaging in other distractions necessary to keep the whole frenetic business from collapse' (1995: 32). Here, Kerr points out an irony: 'Devoted to quality of opportunity, [the multiversity] is itself a class society' (1995: 14), and 'the higher a man's standing, the less he has to do with the students' (1995: 32). Conducting research has become more important than teaching, and a new 'class structure' 
has emerged. At the top is the 'affluent professor' who does not teach, and who generates additional funds from research grants and consultancy work; in the middle are faculty who teach and conduct research; and at the bottom are the 'non-faculty' comprised of non-tenured teaching assistants regarded as support staff.

Kerr also observed a breaking of academic bonds within the multiversity. He believed that increasingly diverse faculty interests led to there being less sense of community on campus, and that 'there are fewer common topics of conversation at the faculty clubs'. Indeed, he argued that faculty members were more tied to national academic discipline bodies and external funding agencies than to their own university (1995: 32-33).

The postmodern university is similarly viewed as being a corporate enterprise and not a community. 'Massification' and the introduction of student loans are thought to have recast students as consumers, changing the previously more intimate dynamic of the teacher-student relationship. Teaching and learning are marked by heterogeneity and change, with innovative uses of technology, mass lectures, and remote learning creating a more individualised educational experience. Like the multiversity, varied employment arrangements for different levels of staff are observed, and we have already noted that due to increased subject specialisation the idea of an academic community is breaking down. There are distinct echoes of Kerr when Zygmunt Bauman observes that 'incumbents of university offices know little, and comprehend even less, of what their next-door neighbours do in their teaching or research hours, and ... would need a dictionary to understand what the occupants of another floor are talking about' (1997: 17). A sense of academic community is also being eroded by the demise of collegial forms of governance in favour of 'distinctly managerial methods' (Smith and Webster, 1997c: 100), a theme to which this chapter now turns.

\section{Example 2: University governance}

For Kerr, the system of government within the multiversity is complex, like that of a city or city state. The multiversity is inconsistent, and there are many groups vying for power, yet, '[a] $s$ in a city there are many separate endeavours under a single rule of law' (1995: 31). While the collective influence of the faculty as a whole may be relatively small, some individual faculties can be relatively autonomous and hold very large influence over the growth of research institutes and distribution of funds in their direction (1995: 18). In the US context, power has 'moved from inside to outside' and public authority can take the form of a lay board, while in the case of state universities, the state department of finance, governor and legislature have been demanding 'increasingly detailed review' (1995: 19). Kerr describes the US system as 'particularly sensitive to the pressures of its many publics' (1995: 20). For private universities this includes 'alumni, donors, foundations, the federal agencies, the professional and business communities'; and for public universities 'agricultural, trade union and public school communities are likely to be added to the list, and also a more searching press'; while state universities have very blurred lines between what is internal and external. The university administration has become more prominent, and has taken on a separate and distinct function. Kerr is undecided on whether the administration has become more powerful or not, however, as the multiversity becomes more complex, 'the role of administration becomes more central in integrating it' (1995: 21-22). Finally, Kerr adds students to the equation, believing that they possess academic influence in the form of which electives they chose as this market choice impacts on which areas and disciplines grow in the university: 'Their choices, as consumers, guide university expansion and contraction' (1995: 15).

Kerr writes in some detail about the role of the multiversity president. He emphasises the importance of governance and not government, so that a university president has many faces, and can work as a mediator to find some consensus between competing interests. 
In the context of the postmodern university, any discussion of university governance is synonymous with neoliberalism, which is viewed as having invaded and negatively impacted upon the university system. Collegial forms of decision-making have been eroded and replaced by managerialism and bureaucratic practices imported from the business sector. In parallel, the audit of teaching and research outcomes provide data for university rankings. Related performance targets are policed by university managers, so that calculative practices have become technologies of government and academics self-regulate their behaviour to be compliant (Miller, 2001; Rose and Miller, 1992).

\section{Example 3: The role of the university within wider society}

The multiversity is located at the centre of society, its knowledge impacting on national and international economic growth and social, political and cultural development. It is also described as having 'fuzzy edges' in that it reaches out to alumni, legislators, commerce and agriculture, and all these groups have pre-existing relationships with one or several of the multiversity's internal communities. We have noted previously that Kerr views the multiversity as being at the heart of mainstream events, and key to economic growth, international competition, and social progress. The multiversity therefore has an obligation to serve the national interest. In this respect, 'It serves society almost slavishly - a society it also criticises, sometimes unmercifully' (1995: 14). And here lies a key difference between the visions of the multiversity and the postmodern university. While Kerr vociferously defends the multiversity's critical function, Smith and Webster lament that the postmodern university 'seems resigned to a pre-set [government and industry] agenda which is narrowly instrumental, one can say passive ... but no alternative vision seems to be available' to the extent that '[t]he confidence of intellectuals in their own activities has been reduced and there is no one available to speak for the university' (1997a: xx).

Engagement with wider society is largely negatively viewed from within the postmodern university, and again this tends to be couched in neoliberal terms. Economic instrumentalism has meant that teaching has become more vocational and that preparing students for the workplace has turned universities into 'sausage factories', and that the requirement in the UK's national Research Excellence Framework for research to meet economic or societal needs has privileged 'impact and use-value over truth' (Donovan, 2013: 32). While some bemoan the 'diminution in the standing and status of academics' (Smith and Webster, 1997c: 100), there is some optimism to be found when considering the postmodern university's possible contribution to society. For Bauman, diverse and fragmented expertise is a distinct asset: 'In the world in which no one can anticipate the kind of expertise that may be needed tomorrow, the dialogues that may need mediation, and the beliefs that may need interpretation ... here the recognition of many and varied ways to, and many varied canons of, higher learning is the condition sine qua non of the university system capable of rising to the postmodern challenge' (1997: 25).

\section{Conclusion}

How was The Uses of the University and the idea of the multiversity received? What Kerr described as the 'conservative side of the professoriate' accused him of 'blasphemy' for saying that within the multiversity undergraduates were often neglected, that for some academics the funding agency rather than an academic's university was their alma mater, that there was a developing faculty class structure on campus, and that research was not being directed towards pure scholarship but was an instrument of national purpose (1995: viii). Others said that what Kerr said was true but that he was too indiscrete to have said it. The 'radical' side of the professoriate accused Kerr of glorifying 
the university as a 'social service station' responding to 'effective market demand' rather than to 'human social needs', and argued that the role of the university should not be integration into national life, but should provide a 'sustained critique of society' (1995: viii-ix).

Kerr wrote in 1994 that he was surprised that on the basis of his book he 'entered into a series of controversies that continue even to this day' (1995: viii). He felt that his lectures were misrepresented by a variety of secondary sources, and he argued that he should have printed in bold type that in his account of the multiversity 'analysis should not be confused with approval or description with defense' (1995: 110). In response to the accusation that the multiversity was presented as purely a service station for society's needs, he regarded multiversities as 'pluralistic, not monolithic, institutions, and thus could and did both integrate into society and simultaneously serve as critics. That was part of their magic' (1995: ix). He felt that the multiversity had many compensations, including: higher salaries and status; that 'rather than a creature on the periphery' some academics 'are at the very centre of national and world events'; there were more opportunities for research; no other institutions could match it 'in the preservation and dissemination and examination of eternal truths', in the 'search for new knowledge' or in 'serving so many of the segments of an advancing civilization'; that while the multiversity was an inconsistent institution, it was 'consistently productive'; and while always subject to change it had the 'stability of freedom' (1995: 33-34).

There are three key criticisms of the idea of the postmodern university. First, that it refers to a late-modern and not a postmodern condition. Donovan argues that the idea of the postmodern university is an artefact of competing instrumentalist, gothic, and postmodernist narratives, which are 'all at heart critiques of the modern or late-modern university'. Second, it follows that the postmodern university does not actually exist, but is 'a mirage' (2013: 34). Third, when we regard the postmodern university as a critique of the late-modern university, it reads as a more negative version of the pre-existing idea of the multiversity. For example, not only are there similar descriptions of university life for students and staff, and the place of the university in wider society (albeit viewed with different lenses), there are the shared motifs of difference, uncertainty, plurality and inconsistency. However, the idea of the postmodern university is generally accepted within the higher education literature, and resonates with the lived experience of UK academics in the UK and beyond.

\section{References}

Bauman, Z. (1997) Universities: Old, new and different. In A. Smith and F. Webster (eds) The Postmodern University? Contested Visions of Higher Education in Society. Buckingham, UK: Open University Press, pp. 17-26.

Clark, B.R. and Trow, M. (1960) Determinants of College Student Subculture. Center for the Study of Higher Education: University of California (Berkeley).

Donovan, C. (2013) Beyond the 'postmodern university'. The European Legacy, 18(1), 24-41.

Griffin, A. (1997) Knowledge under attack: Consumption, diversity and the need for values. In R. Barnett and A. Griffin (eds) The End of Knowledge in Higher Education. London: Cassell.

Kerr, C. (1995 [1963]) The Uses of the University. 4th edn. Cambridge, MA: Harvard University Press.

Krücken, G.A., Kosmützky, A. and Torka, M. (eds) (2007) Towards a Multiversity?Universities Between Global Trends and National Traditions. Bielefeld: Transcript Verlag.

Kumar, K. (1997) The need for place. In A. Smith and F. Webster (eds) The Postmodern University? Contested Visions of Higher Education in Society. Buckingham, UK: Open University Press, pp. 27-35.

Leavis, F. R. and Yudkin, M. (1962) Two Cultures? The Significance of C. P. Snow with an Essay on Sir Charles Snow's Rede Lecture. London: Chatto and Windus.

Miller, P. (2001) Governing by numbers: why calculative practices matters. Social Research, 68(2), 379-396.

Rose, N. and Miller, P. (1992) Political power beyond the state: problematics of government. The British Journal of Sociology, 43(2), 173-205. 
Scott, J. C. (2006) The mission of the university: Medieval to postmodern transformations. The Journal of Higher Education, 77(1), 1-39.

Scott, P. (1997) The postmodern university? In A. Smith and F. Webster (eds) The Postmodern University? Contested Visions of Higher Education in Society. Buckingham, UK: Open University Press, pp. 36-47.

Smith, A. and Webster, F. (1997a) The Postmodern University? Contested Visions of Higher Education in Society. Buckingham, UK: Open University Press.

Smith, A. and Webster, F. (1997b) Changing ideas of the university. In A. Smith and F. Webster (eds) The Postmodern University? Contested Visions of Higher Education in Society. Buckingham, UK: Open University Press, pp. 1-14.

Smith, A. and Webster, F. (1997c) Conclusion: An affirming flame. In A. Smith and F. Webster, (eds) The Postmodern University? Contested Visions of Higher Education in Society. Buckingham, UK: Open University Press, pp. 99-113.

Snow, C. P. (1959) The Two Cultures and the Scientific Revolution. New York: Cambridge University Press.

Tuve, M. A. (1959) Is science too big for the scientist? Saturday Review, 6 June, p.49. 